\title{
Semiotic Analysis of Anna Karenina Movie Posters
}

\author{
Anna Karenina Film Afişlerinin Göstergebilimsel Analizi
}

\section{Prof. Dr. Metin Işık ${ }^{1}$ - Erdal Bilici²}

Başvuru Tarihi: 03.11.2020

Kabul Tarihi: 23.06.2020

Makale Türü: Araştırma Makalesi

\begin{abstract}
Literature and cinema are two arts that help each other to improve. Novels, a sub-branch of literature, allow the film industry to grow and earn more. A novel adapted to cinema constitutes a source for the scenario, which is considered as the main element of the film and makes the novel the popular subject of the script. Adaptation strengthens the relationship between literature and cinema, as a film is a bridge between the literary audience and the movie audience. Anna Karenina, written by Lev Tolstoy between 1876 and 1877, is one of the films adapted to the cinema in 1967, 1997 and 2012.
\end{abstract}

In this study, the posters of the movie "Anna Karenina" designed at different periods will be analyzed. Within the scope of the research, it is tried to determine whether there are similarities or differences between the posters by interpreting the movie posters with the semiotic method.

Keywords: Anna Karenina, Poster, Cinema, Adaptive Film, Semiotics

Öz

Edebiyat ve sinema; sanatı besleyen, alt dalları olan ve birbirinin gelişmesine yardım eden iki sanat dalıdır. Edebiyatın bir alt dalı olan romanlar, film endüstrisinin büyümesine ve daha fazla kazanç elde etmesine olanak tanır. Sinemaya uyarlanan bir roman, filmin temel unsuru sayılan senaryoya kaynak teşkil etmekte ve senaryoya konu olan romanı da popüler hale getirmektedir. Uyarlama bir film, edebiyatsever kitle ile film izleyicisi arasında bir köprü konumunda olduğu için edebiyatın sinema ile olan ilişkisini güçlendirir. Lev Tolstoy'un 1876-1877 yılları arasında kaleme aldığı Anna Karenina da 1967, 1997 ve 2012 'de sinemaya uyarlanan romanlarından bir tanesidir.

Bu çalışmada "Anna Karenina" filminin farklı dönemlerde tasarlanan afişleri analiz edilecektir. Araştırma kapsamında film afişleri göstergebilimsel metotla yorumlanarak afişler arasında benzerlik ya da farklılık olup olmadı̆̆ı belirlenmeye çalışılmıştır.

Anahtar Kelimeler: Anna Karenina, Afiş, Sinema, Uyarlama Film, Göstergebilim

1 Sakarya University, Faculty of Communication, imetin@sakarya.edu.tr, ORCID: 0000-0001-5984-0328

2 Sakarya University, Institute of Social Sciences, erdal.bilici@ogr. sakarya.edu.tr, ORCID:0000-0001-9386-1624 


\section{Introduction}

The poster provides a visualization of a thought or product. On the other hand, it is creative design products that make a message perceptible and visible. While the primary aim was to announce the news in the period when the posters were used, the posters were mostly used to make advertisements with the increasing demand for mass media such as radio and television.

According to Polat and Kavuran (2018, p. 66), with the increasing importance of advertising, the posters intertwined with cinema play a marketing role. Film posters, which are among the creative design products, are visual communication tools that allow to form some connotations about the subject of the film in the audience's mind. The main purpose in the design of the movie poster is to convey the movie content to the audience clearly. In order to fulfill this purpose, the posters should convey the message they want to convey to the audience in the simplest way, according to the characteristics of the areas they use (Tığll, 2012, p. 8). According to Marşap (2013, p. 43), the position of the poster in the cinema was with the emergence of the movie. The posters, which are created to attract the attention of the audience to the film with the visuals, support each other by intertwining with the cinema.

According to Parsa (2008, p. 114), The posters are the result of the opening of the printing press, the spread of the theater, and the emergence and development of cinema. Also, with the development of commercial, industrial, social and artistic activities, the art of the poster has advanced. The common use of movie posters is closely related to artistic activities with the development of printing techniques in the printing press.

When the development of the poster, which is a product of print and graphic design in the cinema sector, is taken into consideration, the quality of the films recorded shows its existence along with the subject and the importance given to the advertisement. With the development of the cinema sector, the posters used in movie theaters also rapidly expanded and improved.

In order to interpret exactly what the information in the poster means, it should be evaluated according to the customs and traditions of the society and the characteristics of the language spoken by the society. According to Polat and Kavuran (2018, p. 68), posters have some political, economic, social and cultural characteristics that constitute the conditions of the period. In line with these features, posters affect the thoughts, feelings and behaviors of the people in accordance with the understanding of the period.

According to Tiğlı (2012, p. 9), posters influence the thoughts of individuals or the masses and turn their ideas in the direction they intended. Likewise, it is possible to foresee what kind of films individuals will focus on, what kind of thoughts they will have about the film, and how they will be affected by the film. A poster designer is expected to create an original visual, and below this expectation is the designer's life experience and perspective on life. (Yesilyurt, 2018, p. 98). If the posters are designed by different people, they may reflect different indicators even if they tell the same movie. In analyzing the movie poster with the semiotic method, it can be said that the perceptual differences brought by the time left a strong trace on the designs. 
According to Polat and Kavuran (2018, p. 66), when the poster designs are examined, they periodically contain differences in themselves. The basis of these differences is that graphic designers can work in parallel with the perspective of art and the perspective of the people of that period. In other words, it is possible to say that the effect of the time of poster design on economic understanding, cultural structure, political life and social building blocks on the graphic design products is substantial.

Poster designs of Anna Karenina films written by Lev Tolstoy and adapted to the cinema in 1967, 1997 and 2012 will be analyzed by semiotic method within the framework of these periodic differences. Despite being the product of the same scenario, the posters of this movie have similarities and differences, as they are handled from the perspective of different designers. In these posters, which will be analyzed by the semiotic method, establishing the relationship between the signifier and the message undertaken by each indicator is important. This is because it creates abstraction in the minds of the audience. The research covers the posters of three adaptations of the novel: Anna Karenina, adapted to the cinema, and sticking to Lev Tolstoy's novel. Semiotics, cinema posters, adaptation films, and Anna Karenina films are limited to the resources obtained as a result of the literature review.

\section{Cinema Posters and Semiotics}

According to Can and Uğurlu (2010, p. 78), posters that are communication and communication tools in cinema consist of a series of images. At this point, the indicators in the posters that play a role in introducing cinema can also be considered as data in terms of semiotics.

In this study where semiotic analysis is done, semiotics; tries to explain how the symbols on the posters create connotations in the minds of the viewers and how the viewers make sense of these connotations. According to Roland Barthes, who developed semiotics, the main subject of semiotics is indicators. It refers to what is shown, which makes associations through concepts and wants to be explained. However, it can be stated that the symbols and signs that cause associations in the mind are indicative (Solak, 2017, p. 176).

According to Tiğlı (2012, p. 26-27), symbolic analyzes are made on posters to create a common language. The purpose of these analyzes is to enable people from different cultures to interpret symbols in the same way. Symbols must be used in accordance with the rules and these symbols should be easy to read. From this point on, the knowledge of the individual will be effective in the interpretation or analysis of the icon in a movie poster.

It is possible to say that movie posters act as a mirror about the movie. Every shape and image on the posters has its own meaning. While the viewer examines the poster, he passes each item through the mind filter and tries to interpret it according to himself. Cinema viewers are directed to the film by reading these texts that give preliminary information about the movie, namely the indicators on the posters (Olgundeniz, 217, p.296). The posters act as a bridge between the audience and the movie, as well as playing an important role in unraveling the 
mystery of the movie. According to Parsa (2008, p. 94), the poster can form a meaningful spiral in the minds of the viewers about the movie that it promotes, and it can also be inferred about the characteristics of the signs used in the poster. The subject of study of semiotics are indicators. Posters can consist of many indicators and there may be a direct or indirect relationship between these indicators (Güney, 2009, p. 131). In semiotics, basically, what the indicators mean, how these indicators are reflected, to whom they reach and their effects on the people they reach are investigated (Olgundeniz, 2017, p. 295). In short, the semiotics tries to explain how it attributes meaning to the objects, states or events considered as indicators. According to Lidov, a study with the semiotics method is carried out to increase our awareness of certain indicators (Horzum, 2008, p. 46). Roland Barthes approaches semiotic analysis from a point of view of meaning. He argues that these meanings consist of denotation and connotation and that they are related to cultural values. He says that the denotation indicates the signifier, and the connotation indicates the signified (Çeken and Yıldız, 2015, p. 139). Since semiotics is based on interpretation, denotation and connotation have great importance.

The dennotation means the signifier, while the connotation means the signified. According to Pektaş (2017, p. 227), a discursive integrity must be achieved with the connotation and denotation it represents while analyzing a poster. When deciphering a movie poster, the first step is to examine the poster's design in a serial dimension. While examining in serial size, the indicators on the poster should be explained in detail. What meanings are attributed to the objects in the poster should be explained. The denotative and connotational responses of the indicators in the poster should be examined and the new meanings they have created as a result of the interaction between them should be revealed (Acar and Yağbasan, 2014, p. 208). In this context, semiotics is an analysis of the meaning of the indicator in the subtext that conveys the meaning.

\section{Literature Review}

When literature review related to the subject was done, it was seen that various similar studies were carried out in this field. There are many semiotic studies on theater posters, cinema films and posters. Within the scope of this study, while making a literature review, mostly cinema posters were analyzed semiotically. In this context, some of the previous studies are as follows; Çeken and Arslan (2016), "An example of a movie poster on the semiotic analysis of images ". In this research, the poster of the movie "Birleşen Gönüller" was analyzed semiotically. However, how semantic structures of signs exist and how semantic structures are transmitted were examined in terms of semiotics. It is aimed to establish the structure of the intellectual factors in all indicators. For this purpose, the indicators such as the war plane, soldier, Nazi emblem located in the lower parts of the actor and actress photo in the movie poster were analyzed semantically.

Yeşilyurt (2018), "Semiotic examination of theater posters and poster designs for play workshop theater "In this study; The visual messages included in the poster designs have been examined and analyzed in terms of semiotics. The processes of finding solutions, visualizing, interpreting and designing the messages to be transferred to the audience have been examined semiotically. 
Tığlı (2012), "Indicators in the design of movie posters": Professor. Yurdaer Altıntaş's movie poster analysis example: In this study, selected movie posters of Prof. Yurdaer Altıntaş are analyzed in terms of semiotics. The semantic features of the posters examined in terms of semantics were revealed.

Okumuş (2016), "The Study of Vurun Kahpeye (1949, 1964, 1973) Films as an Adaptation Example from the Cinema": The novel named Vurun Kahpeye, one of the masterpieces of Halide Edip Adivar, was adapted to the cinema many times. Accordingly, the political and economic conditions of that period were reflected in the films. In addition to this, it has been examined in terms of changing time and discourse effects.

Oskouei (2018) "Interactive Movie Posters and Applications:". In his study, by examining the development processes of the poster, he examined the process of starting interactive media with the movie poster. Interactive movie poster analysis was done within the scope of the research.

\section{Film Adapted for the Movie: Anna Karenina Movie and Analysis of Posters}

Poster designs of Anna Karenina films written by Lev Tolstoy and adapted to the cinema in 1967, 1997 and 2012 will be analyzed by semiotic method within the framework of these periodic differences.

\section{Anna Karenina Movie Summary}

Anna Karenina is a beautiful woman with a high social status. Anna's Husband is a high-ranking officer. They have an ordinary life. The course of certain events changes in the life of Anna who goes to Moscow with the letter she received from her brother. When Anna meets Vronski at the train station, her life begins to change.

Anna's figure tragically shows the view of society to the deceptive wife figure, the hypocrisy of people, the relationship between her husband and her lover. Anna Karenina has been adapted to the cinema many times since it was written between 1876 and 1877. Tatyana Samoylova, Sophie Marceau and Keira Knightley play the character of Anna Karenina, respectively. Anna Karenina, who was adapted to the cinema in 1967, 1997 and 2012, met the audience in these years. The adaptation in 1967 is Russian-made. Anna Karenina's husband is played by Nikolai Gritsenko and her lover Vronsky is played by Vasily Lanovoy. The adaptation in 1997 is English-made. The actor who gave life to Anna Karenina's husband is Alfred Molina, and Sean Bean plays the character of the young handsome officer. The final adaptation in 2012 is again in English. Aaron Johson plays the character of Count Vronsky. The actor who played Alexei Karenin is Jude Law.

\section{Semiotic Analysis of Posters}

These films, adapted to the cinema in 1967, 1997 and 2012, will be analyzed chronologically by semiotics method. 


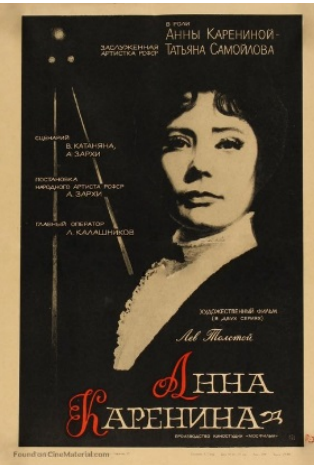

\section{Figure 1. Anna Karenina 1967 Movie Poster}

In the first adaptation of the 1967 movie poster, a black train is approaching behind the portrait of Tatyana Samoylovaya, who plays the character of Anna Karenina. In the poster, the names of the players are written mutually and the image of the train rails is created. The name of the movie is written in large fonts at the bottom of the poster. It attracts attention with its quite plain design.

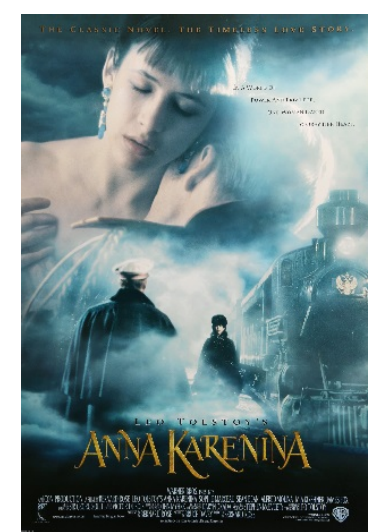

Figure 2. Anna Karenina 1997 Movie Poster

In the poster of the 1997 film, which is the second adaptation, Anna Karenina hugs her lover with her eyes closed. And it is understood that to be a love story. It can be understood that Anna's lover is a soldier (from the clothes he wears).

There is a train and two lovers in the right corner, and the meeting moment of two lovers can be seen. The gray effect of fog on the poster emphasizes the negative atmosphere of the story. The timeless love story in yellow tones on the top of the poster emphasizes that it is a period movie. There is also the text of Anna Karenina, which is the name of the movie, which evokes the work of Tolstoy at the bottom of the poster. At the bottom is the ranking of the writers and cast. 


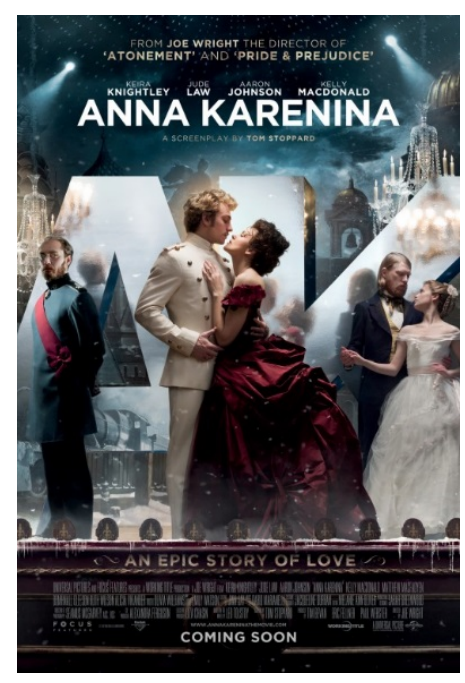

Figure 3. Anna Karenina 2012 Movie Poster

In the poster of this 2012 English adaptation, we see Keira Knighyley and Aaron Johnson, who portray Anna Karenina and Count Vronsky as they dance. On the left side, there is Jude Law with the character of Alexei Karenina, with the loneliness of the spouse deceived, and on the right side, there are other couples of the story. In the background, there are the letters A and K, which are the abbreviations of the name and surname of Anna Karenina, who gave her name to the novel and film. The people belonging to the upper class of the society are described, and besides, there are chandeliers symbolizing the magnificence of the period and monuments considered the symbol of Russia. The name of the director and actors is at the top of the poster. The names of other players are written at the bottom.

\section{Analysis of Anna Karenina Movie Posters According to Barthes}

Barthes explains the relationship in the indicators on the posters as denotation and connotation, moreover, he explains that the denotation reflects the symbol itself, while the connotation reflects the mystery that exists in this symbol. According to Ceken and Arslan, (2016, p. 508), the denotation explains what the indicator is, the connotation is how the indicator is represented. French semiotician Roland Barthes, the rule-maker of these semantic planes, has determined the principles of semiotics as language / word spectrum / declaration, signifer / signified, syntax / series, denotation / connotation " (Girgin, 2017, p. 315).

Table 1. Signifier and Signified Table of Denotation (Movie Poster in 1967)

\begin{tabular}{l|l}
\hline Signifier of Denotation & Signified of Denotation \\
\hline Lead actor & The main hero \\
\hline Train & Travel \\
\hline
\end{tabular}


Table 2. Signifier and Signified Table of Connotation

(Movie Poster in 1967)

\begin{tabular}{l|l}
\hline Signifier of Connotation & Signified of Connotation \\
\hline The large picture & $\begin{array}{l}\text { Lead actor who close to the } \\
\text { audience }\end{array}$ \\
\hline $\begin{array}{l}\text { Small picture, train in the } \\
\text { background }\end{array}$ & Separation \\
\hline Colour: red, white, black & Pessimist, sadness, death, blood \\
\hline
\end{tabular}

As a denotation, the large picture used in the poster of the movie Anna Karenina, adapted to the cinema in 1967, shows that Tatyana Samoylova has the leading role. As a connotation, the large picture shows that the main character is Anna Karenina. The white shirt she wears shows that she is a noble person. It conveys the message that the train in the upper left corner has an important place in the flow of events.

In the poster work of the first adaptation, the body language of the character Anna Karenina carries various clues about the overall functioning of the movie. The sad looks of the main character are in the foreground. These glances, which are frightened, anxious, and sad, are the resolved messages of the connotation.

Red, white and black colors have been used predominantly. These colors, which are used to create a pessimist and sad atmosphere, are the symbols the sad story of the main character.The letters $\mathrm{A}$ and $\mathrm{K}$, which are the first letters of the name and surname of Anna Karenina, written in red and black and bold fonts on the poster, are written in red color evoking the blood.

Table 3. Signifier and Signified Table of Denotation (Movie Poster in 1997)

\begin{tabular}{l|l}
\hline Signifier of Denotation & Signified of Denotation \\
\hline Leading actor of the movie & The main hero \\
\hline Picture of the male & The other players \\
\hline Train & Travel \\
\hline
\end{tabular}

Table 4. Signifier and Signified Table of Connotation (Movie Poster in 1997)

\begin{tabular}{l|l}
\hline Signifier of Connotation & Signified of Connotation \\
\hline The large picture & Lead actor who close to the audience \\
\hline The small picture, male in the background & The other player \\
\hline Train & Meeting \\
\hline Colour: grey, black and yellow & Hazy, pessimist and rich \\
\hline
\end{tabular}

The portrait of Sophie Marceau, which was given as an oversized picture in the film in 1997, reminds her that she was the leading role. It can be understood from the posture of the actor in the background that he is the lover of the lead role. When the male and female figures located next to the train in the right corner are examined, it can be said that the story revolves around this couple. It can be interpreted that a forbidden love story was emphasized with the male actor whose face was not visible in both portraits. It can be said that he is a military officer from the epaulettes on the shoulders of the man. Their outfits give clues that these people are from the 
upper class of society. The costumes of the players contain various information about the region in which they live. The snowflakes falling on the black fur of Sophie Marceau, who plays the character of Anna Karenina, are indicative of this.

The gray tones used intensely in the poster create a foggy air image and turn into a negative atmosphere. The black color creates the impression of a noble and noble class in the clothes of the players. Yellow tones evoke richness. The gold earrings with blue stone worn by the character of Anna Karenina show the sophistication of the nobility at that time. At the top of the poster, to draw attention, it is written that it is a classic novel with yellow color. In addition, it is emphasized that it is a timeless love story. And the most importantly, it is written that Anna Karenina is one of the women who dare to obey her heart in the world of power and privilege. At the bottom, the name of the experinced novelist Tolstoy is written on the text of Anna Karenina, which is written in yellow and in large fonts, and finally the name of the director and the actors respectively.

Table 5. Signifier and Signified Table of Denotation (Movie Poster in 2012)

\begin{tabular}{l|l}
\hline Signifier of Denotation & Signified of Denotation \\
\hline Lead actors & The main heroes \\
\hline Characters on the left & Hero of the second degree \\
\hline Character on the right & The other player \\
\hline
\end{tabular}

\section{Table 6. Signifier and Signified Table of Connotation (Movie Poster in 2012)}

\begin{tabular}{l|l}
\hline Signifier of Connotation & Signified of Connotation \\
\hline The large photo & Lead actors who close to the audience \\
\hline Small photo on the left & Players of secondary importance \\
\hline Small photo on the right & The other \\
\hline Colour: Navy blue, white, red, yellow & Noble, smart, stunning, rich \\
\hline
\end{tabular}

The poster of the last adaptation in 2012 contains other characters of the story. It can be said that the couples in the movie look at each other with love and the loneliness of Jude Law with the character of Alexei Karenin. The big position of Keira Knighyley and Aaron Johnson close to the audience shows that they have the leading role. And as connotation, it can be said that they played the characters of Anna Karenina and Count Vronsky. The portrait of Jude Law, which is slightly smaller than the photo of Keira Knighyley and Aaron Jonson, is portrayed as the other hero of the story, unlike his leading actors.

The costumes of the players contain various clues about the clothing style of the period. The colors and styles the costumes of the male actors give connotation messages about the class or profession of the characters.

On the background of the poster, there are the letters $\mathrm{A}$ and $\mathrm{K}$, which are the abbreviations of the name and surname of Anna Karenina, who are the main character of the story. There are reflections of the places considered as the symbol of Russia in or around these letters. Colors such as navy blue, white, red and golden yellow add meaning to the poster such as nobility, luxury, elegance. At the top of the poster, there is a yellow title introducing the director and the 
names of the actors in the white color just below it. The name of the movie is written with white letters and big font on a bottom line. The names of the players are written in white letters at the bottom of the poster.

\section{Evaluation and Conclusion}

Anna Karenina movie posters, written by Tolstoy between 1876 and 1877 and adapted to the cinema many times, were analyzed semiotically. When the posters of the 1967,1997 and 2012 productions are examined, it is seen that posters with important scenes are designed. Although they adapt the same story to the movie, it can be said that the movie posters contained many technical aspects of the period they were created.

The development of movie posters, which are influenced by technological advances, can also be clearly observed on the impact of Anna Karenina on movie posters. The poster made in 1967 is visually simpler than the other two posters and has more meaning for those who know the story. The first movie poster is more simply designed in Black and White and contains fewer items. In addition to, more colors and characters were used in the second poster. The most information about the movie can be found in the 2012 movie poster because it contains more items.

Anna Karenina movie posters adapted to cinema in different periods have formal differences and there are also points where these posters meet on the common denominator. Similarly, the image of the main character is depicted with large angles to create intimacy to the audience. The other similarity is the size of the font of the movie title and the location of the slogans written in yellow on the posters of the last two adaptations. A love story is emphasized on the poster of the second and third adaptations. Also, the first adaptation poster gives the impression that a woman will travel by train. It is different in the typography used in all three posters. While the train is in the foreground in the first two posters, it is in the background in the last poster. As a result, the posters, which have an introductory role in the movie, contain the same story, even if they were designed in different periods. Furthermore, the message that the indicators on the poster wish to reflect remains the same. 


\section{References}

Acar, M. ve Yağbasan, M. (2014). Minimalist sanat akımına dayalı olarak Yavuz Turgul filmleri ve afiş önerileri. Fırat University Journal of Social Sciences/Sosyal Bilimler Dergisi, 24(2), 205-220.

Asgari Oskouei, A. H. (2018). Etkileşimli film afişleri ve uygulamalar (Yayımlanmış Yüksek Lisans Tezi). Hacettepe Üniversitesi Güzel Sanatlar Enstitüsü, Ankara.

Boztaş, E. (2017). Organ bağıșı temalı sosyal afiş tasarımlarının göstergebilim yöntemi ile analizi. İdil Sanat ve Dil Dergisi, 6(37), 2521-2542. DOI: 10.7816/İdil-06-37-09

Can, A., ve Uğurlu, F. (2010). “Gölgesizler” filmi ve edebiyat sinema ilişkisi üzerine. Selçuk Üniversitesi İletişim Fakültesi Akademik Dergisi, 6(3), 76-84. DOI: 10.18094/Si.38528

Çeken, B. ve Arslan, A. A. (2016). İmgelerin göstergebilimsel çözümlenmesi "Film afişi örneği”. Bayburt Eğitim Fakültesi Dergisi, 11(2), 508-517.

Çeken, B. ve Elif, Y. (2015). Renklerin reklam algısı üzerindeki etkisi: 2012 kırmızı reklam ödülleri. Sanat Eğitim Dergisi, 3(2),129-146.

Girgin, Ü. H. (2017). Sen aydınlatırsın geceyi filminin göstergebilimsel çözümlemesi. Journal of Communication Theory \& Research/Iletisim Kuram ve Arastirma Dergisi, 5(45), 315-344.

Güney, N. (2009). Sinema filmlerinin reklam ve tanıtımında afiş ve fragmanların rolü. (Yayımlanmış Yüksek Lisans Tezi). Marmara Üniversitesi Sosyal Bilimler Enstitüsü, İstanbul.

Horzum, I. (2008). Modernizmin etkisinde doğa içerikli reklamların göstergebilimsel incelenmesi (Yayımlanmış Doktora Tezi). Selçuk Üniversitesi Sosyal Bilimler Enstitüsü, Konya.

Marşap, G. (2013). 2000-2010 yılları arası Türk sineması film afişlerinin gelişimi (Yayımlanmış Yüksek Lisans Tezi). İstanbul Kültür Üniversitesi Sosyal Bilimler Enstitüsü, İstanbul.

Okumuş, M. S. (2016). Romandan sinemaya yapılan bir uyarlama örneği olarak vurun kahpeye (1949, 1964, 1973) filmlerinin incelenmesi (Yayımlanmış Yüksek Lisans Tezi). Marmara Üniversitesi Sosyal Bilimler Enstitüsü, İstanbul.

Olgundeniz, S. (2017). Animasyon sinemasında anlatı ve film afişlerinde kurgulanan görsel kodlar. Akademik Sosyal Araştırmalar Dergisi, 5(46), 290-301. DOI: 10.16992/ASOS.12340

Parsa, S. (2008). Film çözümlemeleri. İstanbul: Multilingual.

Pektaş,Ö,H (2017), Tv reklamlarında göstergebilimsel inceleme ve Türk Hava Yolları "Hayal Edince” reklam filminin çözümlenmesi. The Turkish Online Journal of Design, Art and Communication, 7(2), 226-238. DOI:10.7456/10702100/007.

Polat,B ve Kavuran,T. (2018). Emrah Yücel sinema film afişlerinden New York'ta beş minare ve kill bill film afişlerinin göstergebilimsel açıdan incelenmesi, International Journal of Social Science, 69(2), 65-73, DOI: 10.9761/JASSS7661

Solak, B. B. (2017). Televizyon reklamlarında mizah ve mizahi karakter kullanımı: Banka reklamlarına yönelik analiz. İnif E-Dergi, 1(2), 170-190. 
Tığl1-Tuzcu, İ. (2012). Film afişleri tasarımında göstergeler: Prof. Yurdaer Altıntaş'ın film afişleri çözümleme örneği (Yayımlanmış Yüksek Lisans Tezi). İstanbul Kültür Üniversitesi Sosyal Bilimler Enstitüsü, İstanbul.

Yeşilyurt, Ş. (2018). Tiyatro afişlerinin göstergebilimsel açıdan incelenmesi ve oyun atölyesi tiyatrosu için afiş tasarımları (Yayımlanmış Yüksek Lisans Tezi). Hacettepe Üniversitesi Güzel Sanatlar Enstitüsü, Ankara. 